\title{
The Relationship between Poverty, Conflict and Development
}

\author{
Brian-Vincent IKEJIAKU \\ Research Institute for Law, Politics and Justice \\ Keele University \\ Keele, Staffordshire, ST5 5BG, UK \\ Tel: 44-7944-765-923Ｅ-mail: ike.bvo06@yahoo.com
}

\begin{abstract}
Contrary to the expectations and dreams nourished by many people that the end of the 'Trio-Crisis Initiators' in Africa: Colonialism (1960s) Cold War (1998) and Apartheid (1994), will bring stability and succour to the continent, however, the new era could as well be perceived as a turbulent period. This paper establishes the relationship between poverty, conflict and development (PCD) in analysing instability in the African continent. In its analysis, the paper examines several variable factors that can help in the explanations of the relationship between PCD in Africa. These variable factors includes: economic, political, population, climate and environment, ethnic composition, militarization, poor growth and political corruption. None of these varying factors can unilaterally explain the relationship between poverty, conflict and development as issues behind Africa's instability. However, the paper argues that political corruption stands out as the most persuasive, compelling and primary explanation for the (causal) relationship(s) between PCD, though, it is not an exclusive one. While, the paper recognises that there are both exogenous and endogenous trends that influence political corruption, the paper adopts the endogenous (domestic political corruption) perspective, because political governance is now more controlled at home. The paper employs the human needs theory for analysis.
\end{abstract}

Keywords: Democracy, Poverty, Conflict, Political Corruption, Development, Growth, Human Needs Theory

\section{Introduction}

The African continent over the past three decades, particularly in the 1980s and 1990s has faced greater challenges to stability and progress in all ramifications than ever before. The continent is poor; Oputa (1994) tends to suggest that socio-economic conditions of the Africans have little or no impact on the welfare of the people. In spite of the fact that the African continent exceeds in its size and natural resources the combined territories of Europe, the United States and China, yet most Africans must struggle for bare survival (Seidman et al, 2006). That is absolute poverty: 'poverty qua poverty', the term I coin to describe the practical absolute poverty of Africa, particularly Sub-Saharan Africa where the majority find life excruciating because it is difficult to meet or satisfy their basic needs, such as food, clothing, shelter and education beyond primary school level. It is pathetic that an average African has grown poorer over the past decades, notwithstanding enormous aid disbursement and substantial gains in technology and trade that have helped boost growth in other regions, particularly on the Asian continent (Schaefer, 2005).

In much of Africa, very little economic growth has occurred over the past fifty years. Some countries are even poorer today than they were thirty years ago. Sub-Saharan Africa has had the lowest Gross Domestic Product (GDP) for decades. Statistics confirm that Africa has a population of about 600 million, more than double that of the United States, yet it is estimated that average real GDP per capita growth is $11 \%$ in Africa, which is lower today than it was in 1970 . Evidence shows that 200 million Africans have no access to proper health care, and proper hygiene. Another $47 \%$ are without access to safe water. In some parts of Africa the power supply is constantly interrupted or almost non-existent (Marke, 2007: 1). The Economist (in Wrong, 2004) estimates that 40 percent of the region's privately held wealth is held outside the region. Green and Seidman (1968) argue that there has been structural imbalance in African economies, compared to other regions. It may be contended that this view has been overtaken by time; yet, The World Bank (2005) notes 'Sub-Saharan Africa is the world's poorest continent, with nearly half of its 719 million people subsisting on less than dollar US \$1 per day'. The statistics from the latest MDGs Assessment (UN 2007) that poverty has declined in a number of African countries, does not exonerate Africa from being far the most poverty stricken continent in the world. It is because of Africa's predicament that made Ali Mazrui (in Fapohunda, 2002) one of the most celebrated African writers to assert that Africa is the first home of mankind, yet the last to be made truly inhabitable in contemporary world as a result of poverty and underdevelopment. In fact, the common problem of poverty in Africa is a clear case of 'res iptsa loquito' (meaning the matter speaks for itself), particularly in the Sub-Saharan Africa. 
Again, the countries of Africa, particularly those in Sub-Saharan Africa are a volatile mix of insecurity and conflict. The problem of conflict and insecurity is destabilising the continent's peace process. It is right to argue that no continent that is bedevilled with the problem of peace and stability in its societal milieus could progress. Thus, the dire need for peace in the African countries is a matter that calls for great and urgent concern. This submission is given credence by the views expressed by Solomon and Wart (2005: 4), on African Peace and Security:

Territorial disputes, armed conflict, civil wars, violence and the collapse of governments and ultimately the state have come to represent the greatest challenges to peace, security and stability. On the African continent, these threats have been much more pronounced and indeed have taken on a scale, intensity and frequency that have defied even the imagination of the greatest science fiction.

The fact is that whenever conflict occurs, the development of the society in most times is seriously affected. As Wanyande (1997: 1-2) discloses the costs of conflicts in Africa in terms of loss of human life and property, and the destruction of social infrastructure are enormous. For example, between 1998 and 2002, some four million people died in the civil war in the Democratic Republic of Congo (Report of the Commission for Africa (RCA), 2005: 107). Besides, once conflict occurs, scarce resources are inevitably diverted to the purchase of military equipment at the expense of socio-economic development. While many factors contribute to creating conflicts, this study claims that African conflicts are mainly as a result of 'poverty rooted on political corruption'. Gurr and Marshall (2003) argue that most African conflicts are caused by the combination of poverty and weak states and institutions, and these have had a devastating impact on Africa's development.

The implication of the above discussion is that there appears to be a link between poverty, conflict and development in Africa. This paper aims to reveal that poverty rooted on political corruption is the major cause of Africa's conflict, and this has led to poor development. This study proposes among other things that the denial of basic needs (poverty) by irresponsible governance in most African states have been at the heart of conflict, as well as the continent's development problems. This study therefore pinpoints political corruption as the root of poverty in Africa.

This paper will specifically consider the following issues: Conflict and some of its effects in Africa, political corruption in Africa and political corruption as a causal explanation for the relationship between poverty, conflict and development in Africa. The use of 'Africa' in this paper is solely for clarity, and therefore means the conflicting countries of Sub-Saharan Africa.

\section{Theoretical Approaches to Poverty and Conflict in Africa:}

Poverty is a multidimensional problem that goes beyond economics to include among other things, social, political, and cultural issues. Scholars have been trying to develop a theoretical approach to poverty and conflict for a long time. Some like John Burton (1997), Laune Nathan (2003), Richard Sandbrook (1982) and Ted Gurr (1970) agree that poverty as a result of lack of human needs lead to reactions that result in conflict. The human needs theory championed by Burton (ibid) argues that there are conflict and instability in developing countries because people are denied not only their biological needs, but also psychological needs that relate to growth and development. The overriding importance of this theory is that it understands that needs, particularly basic needs (such as food, water, shelter and health) unlike interest cannot be traded, suppressed, or bargained for; thus any attempt to do this, leads to conflict. According to Aristotle (in Okanya, 1996: 3), social strife and revolutions are not brought out by the conspiratorial or malignant nature of man, rather revolutions are derived from poverty and distributive injustice. Therefore, when the poor are in the majority and have no prospect of ameliorating their condition, they are bound to be restless and seek restitution through violence. No government can hold stability and peace when it is created on a sea of poverty (Ibid).

In Africa the case is that of absolute poverty (poverty qua poverty). This means that lack of basic needs (like food, clothing, shelter and health) in Africa is the seed of conflict (though, as a matter of emphasis - all African countries are not equally poor and equally conflict prone). 'Poverty qua poverty' is a situation no human being would be contented with, because of the agonising pains that follow the lack of these basic needs. Therefore, people in most cases react negatively to such situation, in order to show their grievances and discontent, particularly when the government is corrupt. Conflicts are therefore often caused by an attempt to clamour for these basic needs by violent means. Africa, as a volatile mix of poverty and conflict has continued to be poorly developed. Thus, as long as absolute poverty (which is rooted on political corruption) remains in Africa, conflict is inevitable. The argument of this study is that poverty, conflict and underdevelopment in Africa are traceable to political corruption. Hence the question, how can Africa develop politically (particularly by eliminating political corruption) in order to effectively alleviate absolute poverty; in effect manage conflict in Africa to avoid further human losses? Is development possible in Africa, as the continent is embroiled in conflicts?

It is important to point out that there other theoretical strands, beside the Human Needs Theory (HNT), which can be employed for analysis of PCD in Africa. These include dependency theory, international liberalism and modernisation 
theory, but HNT is adopted because the paper finds it most relevant for analysing basic needs, which is its concentration.

\section{Brief Theoretical Analysis and Explanatory Factors for conflict in Africa:}

\subsection{Modernisation, democratisation and colonisation}

Scholars have emerged with different theoretical explanations for the causes of conflict in Africa. In the face of present crises in Africa, the flaws underlying both modernisation and democratisation theories and the theory of colonialism are being exposed. The long held notion that modernity would result in smooth transition from authoritarian system to democratic system, with gradual elimination of conflict has failed woefully in Africa (Irobi, 2005: 2). Again, the view that the end of colonialism (1960 onwards) - the theory that the end of social, political and economic control of the developing countries by the advanced capitalist nations, particularly the colonialists (Abbah, 1996: 6), would lead to peaceful African states did not stand, as Africa has been besieged with plethora of conflicts since the end of Colonialism.

\subsection{Economic}

The proponents of economic theory contend that the propensity to indulge in violent conflict is higher for low income or less educated people (Ehrlick, 1973: 521-26). A corollary of this position is that poor economic conditions and low quality of life could serve as a breeding ground for conflict. However, for the fact that poor economic conditions might result from different problems bedevilling Africa, economic factors could not fully explain conflicts in Africa. For example, Glaeser (2002) argues against economic factors noting that political leaders often encourage individuals and groups to engage in violence conflict in order to promote and project their parochial and egocentric interests.

\subsection{Militarisation}

Militarisation has also been employed to explain the cause of conflict in Africa. The exponents of this theory argue that violent conflict in Africa could be understood in the series of military weapons that have been employed in devastating and disintegrating many developing countries, particularly in Africa. Mohammed (1999: 1) for example argues that the intensity and frequency of civil wars in developing countries have increased unabated throughout the 1990s. However, Omitoogun (2004: 3) argues that in associating militarization and conflict, caution needs to be taken because rather than the proliferation of arms in the society, it is the welfare-reducing effects of militarisation that causes violence. Besides, when it is appreciated that developed countries with more sophisticated arms than Africa are not in conflict like the later, militarisation as an explanation becomes weak.

\subsection{Ethnicity}

Ethnicity is another crucial explanatory tool to the continent's plethora of conflicts. Theorists believe that ethnicity underlies virtually all conflicts in Africa, since ethnic groups in their bid to compete for scarce resources such as property rights, jobs, education, and social amenities engage in violence. In his study Nnoli (1980) employed empirical evidence associating conflict to ethnic problems. However, Elbadawi and Sambanis (2000: 1) questioned the ethno-cultural and linguistic explanation for conflict in the continent, rather linking Africa's conflicts to other factors poverty, absence of democratisation and over dependence on natural resources. Collier (1997) argues that Africa is not inherently prone to war as a result of ethnic disparities, but the continent's experiences of many wars, is fundamentally because it is poor and poverty is both the cause and consequence of Africa's wars.

\subsection{Population}

Population is another important factor to African conflicts. It is argued that there has been tremendous increase in the population of developing countries, which has superseded economic growth. According to the RCA (2005: 112), between 1980 and 2002, the population of Sub-Saharan Africa has grown from 383 to 689 million people, which is an increase of 80 percent. In contrast, in much of Africa, very little economic growth has occurred over the past fifty years. For example, no other region of the world more urgently needs economic growth. However, instead of the desperately needed economic growth, Sub-Saharan Africa as a region has seen a decline in per capita GDP from $\$ 575$ in 1980 to \$524 in 2003 (World Bank, 2005, in Schaefer 2005)..Some countries are even poorer today than they were thirty years ago. Sub-Sahara Africa has had the lowest Gross Domestic Product (GDP) for decades (Marke, 2007: 1). Supporters of this explanatory tool therefore argue that high population growth has made things difficult in developing countries, as people have to scramble for available resources, which results to conflicts. However, countries like India, China and others have larger populations than most African countries, but they are not in violent conflicts like Africa.

\subsection{Volatile climate and environmentalism}

The argument that African conflict is as a result of volatile climate and elementary forces (such as drought and famine) in its environment that have affected growth, has been challenged by scholars. Sen (1999: 61-63) for example argues that famine, drought and related disaster are not allowed to occur in democratic polities because people have established mechanism to compel governments to address their needs and pressing problems. Also, Wisner (1988) argues that 
drought and other environmental problems cannot directly explain the 1986 disaster that hit 13 African countries since ten of these thirteen affected countries have experienced other problems such as war, civil strife, destabilisation (including apartheid) and a massive influx of refugees.

\subsection{Political corruption}

Trends of events in the past three decades reveal that political corruption is the 'root' cause of conflict in Africa. The contention here is that political corruption by sapping the economy of Africa renders the continent poor or worsens its poverty situation. And this renders most of the states in the continent incapable of providing the basic needs of the people. Burton's $(1979,1997)$ human needs theory on conflict and conflict management recognises the indispensability of these needs, by pointing out that wherever such non-negotiable needs are not met, conflict is inevitable. Since political corruption is perpetrated by leaders entrusted with a nation's coffers, the masses normally react by engaging in violence. According to the United Nations Human Development Report (in Fapohunda, 2002: 26), sixty percent of Africans live in abject poverty. The problem of poverty is compounded by the issue of corruption of the state resources, $37 \%$ of Africa's assets are held abroad; Fapohunda (Ibid) argues that this figure, the highest for any region in the world, was more of the fruit of corruption. Egbo (2002: 289) maintains that,

'this is public money siphoned overseas by corrupt political and military rulers for their personal use, the problem of poverty and breakdown among most third world countries has its root in the illegitimate and arbitrary methods of these men... the growth of the society becomes stunted'.

While all these competing factors are useful in the explanations of the rise in conflict in Africa, this paper sees political corruption as the most persuasive. In other words, while all these factors contribute to conflict in Sub-Saharan Africa, political corruption is the most compelling.

\section{Conflict in Africa and its consequences:}

Africa has been experiencing a plethora of conflicts endangering the continent's international order and development over the last three decades, particularly in the 1990s. Africa could be said to have witnessed four major types of conflicts, these include secessions, civil wars, regional conflicts, and internal crises.

Secession is a situation whereby a particular region, community or enclave strives to separate or withdraw from a state's control or authority; that is an attempt to withdraw from a state's sovereignty and organise its own government and separate institutions. Biafra's dogged efforts to secede from Nigeria (1967), the notorious Katanga rebellion in Congo (now DRC 1970s), are notable examples. Usually, the seceding entities pursue autonomy, instead of formal or total independence.

Another form of conflict is civil wars (wars between government state army and the armed forces of a rebel government); these usually start as minor internal crises, but develop to fully fledged war, which are fought with conventional weapons. Although, it is extremely difficult to draw a line between civil war and regional or international wars, many civil wars have been connected with regional or inter-state conflicts. Countries in Africa, particularly those in the Horn of Africa, and for example Democratic Republic of Congo (1998-03), Somalia (1998), Sudan (since 2003), Angola (1975-02), Rwanda (1990-94), Kenya (1991/92, 1997), Ethiopia and Eritrea (1998-2000) and others have all involved in civil wars (Wayande, 1997)). Salih (1999: 141) observes that:

The states and peoples of the Horn of Africa have duly been compelled to choose between total collapse through civil wars or political survival with an uncertain future...

Regional conflict in the continent has been classified as being 'irredentist' (Ruiz, 1997: 1) in character. Conflict is termed as being irredentist when one country harbours some territorial ambitions over another country. Good examples of this form of conflict in Africa include the Somali claim on the Ogaden region of Ethiopia (in early 1970s), and Libya's strive to annex part of northern Chad (early 1980s). The case of Tanzania and Uganda (1979) is a similar conflict, since Tanzania (under President Julius Nyerere) projected its forces over Uganda, in a bid to oust the Ugandan leader (President Idi Amin). Also the combined efforts by some African countries in overthrowing the Mobutu Sese Seko's government in Zaire (1997) are yet other regional conflicts (Wayande, 1997).

Internal crises here mean disturbances of any kind which affect the state of peace and security, these among others include rampages, riots, and violent demonstrations. The Soweto riots in apartheid South Africa in 1976, Fanatical cult killings in March 2000 associated to the movement for the restoration of the ten commandments of God, also the Bryanda riots of 1994 (in Uganda), and series of students' riots in Nigeria between 1999 and 2006 are germane.

Conflict has destabilised most African countries, Wanyande (1997: 1-2) discloses that the costs of conflicts in Africa in terms of loss of human life and property, and the destruction of social infrastructure are enormous:

Hundreds of thousands of people have been killed in many of the countries in which the conflicts occur. Many others have also suffered and continue to suffer untold psychological trauma associated with conflicts... once conflicts occur, 
scarce resources are inevitably diverted to the purchase of military equipment at the expense of socio-economic development (Ibid).

The Report of the Commission for Africa also notes that conflict causes as many deaths in Africa each year as epidemic diseases and is responsible for more deaths and displacements than famine or flood. When people are forced to flee their homes, poverty associated ailments such as malnutrition and diseases follow. Those who suffer most from conflicts are the poor and vulnerable, including children and women. Statistics reveal that there are 13 million displaced people in Africa, particularly due to conflicts and 3.5 million refugees (RCA, 2005: 107). Example includes Northern Uganda (2005), Kenya (1991/92), Rwanda (since 1994) and others. Making brief reference to the report of the commission of Africa (Ibid):

Out of sight of the world, in the biggest death toll since the Second World War, around 1,000 people die every day in the Democratic Republic of Congo. It is only one of Africa's many conflicts. In recent decades Africa experienced more brutal coups, drawn .... and bloody instability than any other part of the world.

The costs of conflicts are horrific, and in many cases conflicts wiped out the achievements of decades of economic and social development. Armed conflicts, in particular, involve complete economic paralysis, immense social costs and trauma, political quagmire and disintegration, as well as serious environmental degradation and dilapidation.

The RCA (2005: 161) also notes that some conflicts, like violence in Darfur, have been of high intensity, however, it observed that 'there are countless smaller conflicts, such as those between herders and cultivators that are to be found in many parts of Africa, which are no less vicious'. Violence from these smaller conflicts also causes as many deaths in Africa as do diseases. For example, the human cost resulting from localised conflicts is devastating, since many are even sent to a 'state of limbo':

Millions of lives have been lost... As a result of 'localised' conflict in Nigeria, for example, at least 10,000 people lost their lives between 1999 and 2003, and an estimated 800,000 were internally displaced. More people have been forced to flee their homes in Africa than anywhere else in the world; many ending up in the slums of already - over crowded cities and towns. Malnutrition and disease increase. And those who suffer most are the poor and the vulnerable. War and conflicts does not only harm people. It destroys roads, bridges, farming equipments, telecommunications, as well as water and sanitation systems. It shuts down hospitals and schools. It slows trade and economic life, sometimes to a halt. The very fabric of society is torn asunder (RCA, 2005: 38).

The consequences of conflicts are much wider; conflict also weakens the stability of Africa and even extends its 'destructive tentacles' to global peace - 'instability in Africa undermines global security. States weakened by strife increase international refugee flows. They also become havens for international terrorist organisations...' (RCA: 38). In these ugly trends, it may seem odd to talk of optimism in most African countries where conflicts have become common, as in Nigeria (since 1985), apartheid South Africa (1948-1994), Mozambique (1976-1992) and DRC (1996-2001); others include Sudan (1983-2003), Somalia (1981-2002), Sierra Leone (1991-2000), Liberia (1989-2003) Rwanda (1990-ongoing), Burundi (1991-onging), Angola (1975-2002) and host of other African countries (Uppsala, 2003).

\section{Corruption in Africa}

The magnitude of corruption in most African countries, to say the least is alarming, terrific and disheartening. Corruption by political leaders has been identified as one of the major causes of poverty, and the failure in the development of developing countries, particularly in Africa. The incidence of corruption remains one of the greatest challenges of democracy in the continent as virtually all democratic experiments are associated with reports of hyper-corrupt practices (Okafor 2004: 98). The embezzlement of public funds by unscrupulous and ineffective leaders of most African countries leads to poverty, high debts and other socio-economic associated problems in these countries.

For instance, focusing exclusively on the top leadership, Transparency International estimates that Mobutu in Zaire and Abacha in Nigeria may have embezzled up to US $\$ 5$ billion each (in Azmi, Daily Times 2005). According to Global Witness (in Ibid), several current leaders in Africa are plundering their own treasuries. Among them are Angola's President Jose Eduardo dos Santos, who it says keeps large sum in bank accounts abroad, and Equatorial Guinean President Teodoro Obiang, who calls oil revenues a 'state secret'. The Mwai Kibaki government in Kenya, which ousted President Arap Moi in an election in 2003, is investigating embezzlement to the tune of \$1billion by former officials, the notorious 'African Big Man' the late President G. Eyadema of Togo was very corrupt.

Campbell (2004) observes that Billions of pounds, enough to pay for the entire primary health and education needs of the world's developing countries are being siphoned off through offshore companies and tax havens. Aid organisations are alarmed that money which should be used for building the infrastructure of the poorest countries is being hidden in the havens by corrupt politicians and multinational companies exploiting tax loopholes (Ibid). In 1999, The Economist (in Azmi, 2005) estimates that African leaders had \$20bn in Swiss bank accounts alone, twice the amount that Sub-Saharan Africa spends on servicing debts. A recent piece of research reveals that there was a high level of 
corruption in South Africa, particularly during the apartheid period. The apartheid government was a corrupt system of governance, in summary:

A near monopoly on money, power and influence were in the hands of a minority and they used this to either violently suppress the majority or, at least, transfer resources in order to stave off the inevitable revolution (Vuuren, 2006: 37).

Further more, roughly 3,000 member of African elites (the majority present and former political leaders), had Swiss Bank accounts totalling 33 billion dollars. One high official even owned a bathtub made of solid gold (Dorman, 1993: 10). In spite of these monumental accumulations, 'these factionalized neo-patrimonial African elites still do not constitute an ascendant bourgeoisie. They have neither the will nor the independent power base to enforce productive priorities or discipline upon the state apparatus' (Okafor, 2004: 99); thereby making poverty alleviation, peace and sustainable development far from realisation in most African states. There is no comparison for corruption in Africa with those of other regions. In analysing political corruption with regard to its relationship to the different rates of economic development in Africa and Asia, an excerpt from the Economist (in Calendar online 2007) is telling:

One of the factors behind the differing economic development in Africa and Asia is that in the former, corruption has primarily taken the form of rent extraction with the resulting financial capital moved overseas rather invested at home (hence the stereotypical, but sadly often accurate, image of African dictators having Swiss bank accounts).... In contrast, corrupt administration in Asia like Indonesia under Suharto's have often taken a cut on everything... but otherwise provided more of the conditions for development, through infrastructure investment, law and order, etc.

The implication of the above statement is that political corruption in Africa impacts negatively to the economic development because African leaders rather than investing their stolen wealth in the continent (like their Asian counterparts), stash them abroad.

\section{Political Corruption: Causal Link - Demonstration and Explanation for PCD in Africa:}

Authoritative sources have associated poverty in Africa to corruption. Sachs and his collaborators at the Millennium Project, for example argue on the implication of corruption on poverty in Africa. They contend that the quality of governance is proportionate to the amount of money available for it, and adjusting a number of corruption-related indicators for poverty, they found that African governance is not bad by international standards, pointing out that poor countries cannot afford the corruption controls available in better-resourced ones (Sachs et al, 2004: 3-4). The significance of their argument to this paper is that there are certainly 'corruption-related indicators of poverty' in Africa that need to be adjusted (these include embezzlement, political patronage, money laundering, bribery, invoicing and over estimation of project and contract); this things impacts on governance negatively in Africa. Just as UN Secretary General Kofi Annan notes,

'Corruption is found in all countries - big and small, rich and poor - but it is in the developing world that its effects are most destructive. Corruption hurts the poor disproportionately by diverting funds intended for development, undermining a Government's ability to provide basic services, feeding inequality.... Corruption is a key element in economic under-performance and a major obstacle to poverty alleviation and development (in UNODC, 2005: 92).

Wentling (2002: 5) castigates corrupt, oppressive leaders in Africa, and suggests that what is most needed is a consistent and aggressive "tough love' diplomacy that refuses to deal with leaders who have fortunes stashed away in foreign bank accounts, and steps up support for legitimate, non-violent opposition groups, while most African states sink deeper into an almost irreversible morass of poverty and chaos.

Currently, there are further corruption charges against five African leaders and their families who used embezzled funds to buy homes in France: These are Gabon's President Omar Bongo, Republic of Congo President Denis Sassou Nguesso, Burkina Faso President Blaise Compaore, President Teodoro Obiang Ngeuma of Equatorial Guinea and Angolan President Jose Eduardo dos Santos (The International Herald Tribune, 2008). The United Nations Office on Drug and Crime notes that siphoning off funds by wealthy elites is doubly problematic in Africa, as much of this graft is immediately invested outside the continent, and that about $40 \%$ of all African private portfolios are held overseas, and this share is likely to be even greater when the funds have been obtained through corruption. (UNODC, 2005: 91). It is therefore because of the devastating level of political corruption in Africa that Jeremy Pope, one of the founders of Transparency International, labelled the African model as 'lootocracy, you don't find it anywhere in the world' (in Wrong, 2005).

There is a contrary view that African poverty is due to poor economic growth; Marke (2007:2) argues that in much of Africa, very little economic growth has occurred and some countries are even poorer today than they were thirty years ago. Also according to J. Bradford Delong of California, Berkeley (in Marke, Ibid), 'the twentieth century has been the century of increasing wealth in the industrialised economies: in material and standard of living, but for the majority of Africans, it has been an era of negative growth...' 
However, studies have shown that corruption is the major factor negating 'growth' in Africa. The negative impact of political corruption on investment predominantly affects economic growth. The IMF for example (in Mauro 2004) notes, 'there is a close association between corruption and slow growth, as well as between corruption and political instability'. Though the IMF just points out the association, however, the World Bank (in UNODC, 2005: 81) agrees that by distorting the rule of law and weakening the institutional foundation of economic growth, corruption is the single greatest obstacle to economic and social development; noting that the harmful effects of corruption are especially severe on the poor, who are hardest hit by economic decline, and are the most reliant on the provision of basic needs and public services.

Political corruption thus has a deleterious effect on poverty or aggravates the existing state of poverty in most African states. And it is likely that poverty caused by agents particularly political leaders entrusted with the nation's wealth could be reacted against by the poor masses in a way of engaging in conflicts as a means of addressing their plights, because of their unmet human basic needs. These conflicts have many consequences since the people commit other atrocities to vent their aggression. As the World Bank argues in its October 2004 paper 'Post-Conflict Peace Building in Africa', conflict tears the fabric of the society, with the overall effect of lowering ethical standard and creating an environment that breeds crime (World Bank, 2004). This does not augur well for meaningful development.

Yet, another counter argument according to Nwankwo (1995: 218-221) is that in addition to the problems of hunger and poverty created by what he calls 'irresponsible leadership' (Ibid: 219); there are also the problems of poverty and want engendered by structural dislocation and mass dislocation of people. With millions daily losing their means of livelihood, and their lands being increasingly unproductive due to elementary forces, destitution sets in, with attendant malnutrition, disease and death. Material impoverishment and spiritual alienation of Africa's millions add to the problem of slum and shanty dwelling, and the evolution of sub-culture of crime, violence, civil unrest, prostitution and other forms of social and moral depravity. This in turn reduces the percentage of the active population engaging in productive and creative ventures, compounding the problems of development (Ibid).

However strong Nwankwo's contention might be, the true situation is that all socio-economic dislocations and other elementary forces, which he claims causes poverty, leading to instability and poor development, is possible in countries that lack political development (and this study will show that political development is incomplete in Africa unless there is an 'absence of political corruption'). Just as Sen (1999: 61-63) argues, famine, drought and related disasters are not allowed to occur in developed and democratic polities because people have established mechanisms to compel governments to address their needs and pressing problems. And Daniel Kaufman, the World Bank Institute's global governance director (in CIOB, 2004) notes that World Bank research has revealed a 400 per cent governance dividend where there was good governance and corruption was under control. Countries that improve on corruption could expect in the long run a four-fold average increase in incomes per capita. Thus a country with income per capita US $\$ 2,000$ could expect to attain $\$ 8,000$ in the long run by making strides in controlling corruption. Similarly, such a country could expect on average a 75 per cent reduction in child mortality and improvement in its poverty stance.

The above contention needs to be substantiated with more evidence; Japan and Hong Kong for example have a weak climate, coupled with negligible natural resources. Yet these two countries (like other New Industrialised Countries 'NIC') conquered their environment because their developed political sectors invested in technology (Marke, 2007: 3) Similarly, Singapore, with a population of 4.5 million (July 2007), which became a British colony in 1867 is neither poor, nor is wide-spread conflict common there, and it is very developed and business operates in a corrupt-free environment, since the leaders are not corrupt and they were able to meet the basic needs of their citizens. They all have a low level of corruption (with impressive ratings of 7.6, 8.3 and 9.4 respectively, see CPI Transparency International, 2006). In Sierra Leone (which became a British colony in 1808), with a population of 6.1 million (July 2007 estimate) is endowed with substantial mineral, fishery and agricultural resources, but is extremely poor like many Africa countries and corruption, particularly political corruption is endemic in the country as in many countries in the continent, and the basic need of the citizens are not met (ibid, see also Appendix A).

The argument that African poverty has much to do with a population is also pertinent. For example, the size of the population between 1980 and 2002 in Sub-Saharan Africa grew from 383 to 689 million, suggesting an increase of $80 \%$ (RCA, 2005: 112), while growth rate declined from US $\$ 575$ in 1980 to $\$ 524$ in 2005 (Schaefer, 2005). Though the African population undoubtedly is increasing and impacting on Africa, however, when it is appreciated that African population is still young (the youngest among all the continents), 44\% of Africa's population is under 15 years old, compared with only $34 \%$ in South Asia and $28 \%$ in East Asia (RCA, Ibid), then it stands to reason that this young population should be active and therefore an asset to Africa. A possible explanation is that majority of African leaders have exploited its youth, the national wealth, which the political leaders could have used in empowering the youths, particularly the investment which creates and safeguards sustainable jobs for the youths (that will enable them meet their basic needs) is either out-rightly embezzled or corruptly stashed away in foreign banks by these leaders, thereby leaving the youths to idle away in hunger. 
Historically, when youths are not engaged in meaningful work and are lacking the basic necessities, they bring attention to their plight by engaging in destructive behaviour (Marke, 2007: 7), this underscores the importance of Human Needs Theory. This view point substantiates the argument of this paper that when youths cannot bear their poverty (particularly lack of basic needs), caused or worsened by political corruption of most African leaders (who appear to be above the law or the law themselves) anymore, they react by engaging in conflict, with its negative effects, which stunt development. The case of youths in the Niger-Delta conflict in Nigeria is a good example, the youths committed lots of atrocities, including the kidnapping of UK expatriates (Onyeiwu, 2004: 6). This is also the reason why prisoners in Africa are mostly the poor who did little or nothing, just as Wentling (2002: 4) critically argues:

As long as political elites and the wealthy can do as they please without fearing any kind of legal sanctions, the huge and growing gap between the great mass of people who have little and the small percentage of the population who possess much will grow. Corruption (particularly by leaders) is endemic throughout the continent and at virtually all levels of society. In fact, sometimes Africans who defraud the government or private firms to enhance the status of their family are looked upon as role models than criminals. Justice is very much lacking: small-time thieves who steal food for themselves or their families are severely punished while big government officials who embezzle millions from the state treasury and live grossly opulent lives are applauded.

The CIOB (2004) points out that the embezzlement of public funds by unscrupulous and corrupt leaders of developing countries leads to poverty, high debts and other socio-economic problems that impact negatively on development. Irobi (2005: 1) states that the countries of Sub-Saharan Africa, including Sierra Leone, DRC, Ivory Coast, Liberia and so many others are a volatile mix of insecurity, instability, corrupt political institutions and poverty. However, the argument so far suggests that it is the corrupt political institutions, particularly political corruption that causes or worsens poverty (the lack of basic needs) that leads to instability in Africa.

As explained, my argument is that political corruption causes or worsens the state of poverty, which leads to conflicts, with the negative impacts that hinder development.

In Table 1 (below), Kenya is employed for illustration, this Table shows that in Kenya, by the time President Arap Moi entered into power, poverty in that country was at $27 \%$, Gini Coeficient of 0.40 (Kayizzi-Mugwerwa, 2001: 6) conflict was low, and GDP was between 3\%-4.2\% (Okafor, 2004: 67) however, during his tenure (1978-2002), Arap Moi embezzled the sum of \$1billion, official figure (Azami, 2005). Within this period, particularly in 1991/92, poverty increased to $30 \%$, Gini rose to $0.49 \%$ (Kayizzi-Mugwerwa, 2001) conflict was severe within this period - in 1991/92 and July 1997) (Wayande, 1997; 6) and development in Kenya was stunted, since her GDP came down to 2.1\% in 1991, $0.5 \%$ in 1992 and $0.2 \%$ in 1993 (Okafor, 2004).

It is interesting to note too, that Kenya transited from the corrupt low-achievement leadership of Arap Moi to Mr. Mwai Kibaki in 2003, yet the situation has not changed (ibid). While President Kibaki is investigating the embezzlement of $\$ 1$ billion by his predecessor, credible allegations of political corruption under the new regime are currently on board. For example, in an open revelation and without mincing words, the British High Commissioner to Kenya has stated that 'the new corruption entered into by this government may be worth around $\$ 188$ million (Azami, 2005). This is the case with Nigeria, and was particularly so during the regimes of Ibrahim Babangida and Sani Abacha. It was also the in apartheid South Africa, particularly during the tenures of P. Botha and F. W. De Klerk. Another case is Zaire, during the regime of S. Mobutu. These are in addition to the African countries (Angola, Equatorial Guinea, Liberia, Morocco and Togo) as demonstrated in the table (see Appendix A). Recent studies support this, for example the studies on the Gambia, Mozambique and Ghana in 2004, suggest that corruption allows the rich, particularly political leaders in Africa to avoid paying taxes (UNODC, 2005: 91). This fuels further income inequality (widening the gap between the rich and the poor), which is highly associated with conflict and has a negative effect on growth and development.

However, a comparative assessment with some countries, for example Botswana (the continent's model of stability and good governance), Mauritius and South Africa (post apartheid), suggests that in these countries with low records of political corruption (these countries scored above 4.2 global average in the most recent '2006' Transparency International - corruption perception index, 2006), their poverty level is low, for example, Botswana has just $23.5 \%$ population of those on poverty below \$1 a day in 1990-2004 (UNDP Human Development Index, 2006) and wide-spread conflicts are uncommon (as illustrated in Appendix B). Furthermore, there is viable development, since Mauritius is in the High Human Development, Botswana and South Africa are impressive in the Medium Human Development, for example, they have 100, 95 and 88 respectively on population with sustainable access to an improved water sources, comparative to other African countries, particularly the Sub-Saharan ones (UNDP Human Development Report, 2006).

In Table 2 (below) The entire Africa and Sub-Sahara were also used for illustration, this Table suggests that the entire Africa and Sub-Sahara, since the past three decades or more (particularly mid 80s and 1990s) statistics reveal that political leaders have stolen about $\$ 33$ billion; this has caused or worsened poverty, making half of the Sub-Sahara's live on less than 65 US cent a day, leading to over 32 conflicts, which has resulted in a rise in crime rates to $8 \%, 6 \%$ and 
$4 \%$ for burglary, assault and robbery, respectively. This has been accompanied by a decline of $0.8 \%$ in development in Sub-Saharan Africa (UNODC, 2005: 2).

\section{Summaries and conclusion}

In summation, my argument is that corruption, particularly political corruption directly undermines democracy and governance by destroying the trust relationship between the people and the state. An indispensable obligation of the state is to provide the basic needs of its people and also to ensure the safety of its citizens. When the state fails to fulfil this obligation, or provides for some groups, but not for others, or worse when the leaders are corrupt, the people effectively reclaim their right to use force (conflict) in the resolution of disputes, often with disastrous consequences, such as a rise in crime and stunted development. Thus, my argument is that 'Political Corruption (POL C) causes or worsens Poverty (POV), which leads to an increase in Conflict (C), which in turn leads to the stunting of Development (DVP). That is POL $\mathrm{C} \rightarrow \mathrm{POV} \rightarrow \mathrm{C} \rightarrow \mathrm{DVP}$. In conclusion, though, there are no doubt, additional explanatory variables and theories for the relationship between poverty, peace and development in Africa, as discussed; it is my argument that political corruption is the major and most persuasive causal factor and the human needs theory most relevant for this paper.

\section{Bibliography}

African Forum and Network on Debt and Development (2007), Nigeria: Foreign Debts, Stolen Wealth, IFS and The West, A case study': AFRODAD.

Atojoko, S. (2003), 'Rape of Nation' Newswatch. Feb. 24, 2003.

Azami, R. (2005), 'Profligacy, corruption and debt, Daily Times (Pakistan) February, 10, 2005, at http://www.odiousdebts.org/odiousdebts/index.cfm? $=$ content\&ContentID=12387 (05/02/07).

Burton J. (1997), 'Violence Experienced: The Source of Conflict Violence and Crime and Their Prevention', Manchester University Press: New York.

Campbell, D (2004), 'Havens that have become a tax on the world's poor', Guardian: UK, 24 September, 2004, available at http://www.odiousdebts.org/odious/index.cfm?DSP (05/02/07).

Chartered Institute of Building (2004), World Bank finds corruption is costing billions in lost development power, CIOB September 29, 2004, at http://www.odiousdebts.org/odiousdebts/index.cfm...ID=11519 (05/02/07).

Collier, P. (1997), The Role of the State in Economic Development: Cross Regional Experience: Plenary paper presented at the AERC Research Workshop, 6-11 December; Harare, Zimbabwe.

Commission for Africa (2005), Our Common Interest, The Report of the Commission for Africa: CA.

Dorman, R. (1993), 'Africa's Despots and Their Lots', Tell October 13, 1993.

Egbo, S. (2002), Nigeria and the world: A treatise on foreign policy, John Jacob's Classic Publishers Ltd: Enugu.

Ehrlich, I. (1973), Participation in Illegitimate Activities: A Theoretical and Empirical Investigation. Journal of Political Economy, May, 81:3, 521-65.

Erikson, M. and Wallenstein, P. (2004), 'Armed Conflicts, 1989-2003: Journal of Peace Research, Vol. 41, No. 5, $2004.625-636$.

Fapohunda, O. (2002), 'from OAU to AU: The Challenges to Human Rights, Vanguard: Lagos, $2^{\text {nd }}$ Aug.

Glazer, N. and Moynihan, D. (1975), eds. 'Ethnicity and Experience', Cambridge, Mass: Harvard University Press: Atlanta Georgia.

Green, R. and Seidman, A. (1968), 'Unity or Poverty?' The Economies of Pan Africanism Hamandsworth: Penguin.

Gurr, T. (1970), Why Men Rebel: Princeton.

Hoffman M. (2004), Surveys says corruption rampant across globe, Business Report (South Africa) October 21, 04, at http://www.odiousdebts.org/odiousdebts/index.cfm...ID=11693 (05/02/07).

International Herald Tribune (2008), French prosecutors probe embezzlement accusations against African leaders at http://www.iht.com/bin/print.php?id=6211623 (12/01/08).

Irobi, G. (2005), 'Ethnic Conflict Management in Africa: A comparative Case Study of Nigeria and South Africa', Conflict Research Consortium: University of Colorado.

Kayizzi-Mugerwa, S. (2001), Globalisation, Growth and Income Inequality: The African Experience; Working Paper No. 186 (Formally Technical Paper No. 186); Research Programme on: Empowering People to Meet the Challenges of Globalisation: OECD Development Centre.

Marke, D. (2007), 'Will Africa Ever Be Able To Replicate Successful Economies? December 16, 2007. 
Mauro, P. (2004), The Persistence of Corruption and Slow Economic Growth, IMF staff papers Vol. 51, No1, 2004.

Mohammed, N. (1999), Civil Wars and Military Expenditure: A Note prepared for presentation at the World Bank's Development Economic Research Group (DECRG) launch conference on 'Civil Conflicts, Crime and Violence', World Bank, Washington, D.C; 22-23 Feb; 1999.

Nathan, L. (2003), Crisis Resolution and Conflict Management in Africa; Centre for Conflict Resolution, University of Cape Town: South Africa.

Nnoli, O. (1980), Ethnic Politics in Nigeria, Fourth Dimension Publishers: Enugu

Nnoli, O. (1981) eds., 'Path to Nigeria Development', Zed Press: California.

Nwankwo, A. (1995), The African Possibility in Global Power Struggle, Fourth Dimension: Enugu.

Okafor, C. (2004), Neo-Democracy and Poverty Management in Africa: Mercury Bright Press: Awka, Nigeria.

Okanya, O. (1996), Political Thoughts, an Unpublished Mimeo, Department of political Science, Enugu State University: Nigeria.

Omitoogun, W. (2001), Military Expenditure and Conflict in Africa: DPMN Bulletin, Vol. VIII, No. 1, July.

Onyeiwu, S. (2004), On the Economic Determinants of Violent Conflict in Africa: Preliminary Evidence From Nigeria, Helsinki: Finland.

Oputa, L.. (1994), 'Who is Who Among the Poor', The Guardian on Sunday, April 17, 1994.

Sachs, JD., McArthur, JW., Schmidt, G., Kruk, M., Bahador, C., Faye, M., \& McCord, G. (2004), Ending Africa's Poverty Trap, Mimeo: available at www.unmillenniumproject.org, (17/2/07).

Salih, M. (1999), Governance, Information and the Public Sphere: UN Economic and Social Council; Economic Commission for Africa, Third Meeting of the Committee on Development Information (CODI): Addis Ababa: Ethiopia, 10-17 May 2003.

Sandbrook, R. (1982), The Politics of Basic Needs, Heinemann: London.

Schaefer, B. (2005), How the Scope of Government shapes the Wealth of Nation, Heritage Lectures: No 925 Delivered December 1, 2005.

Seidman, A. Seidman, R and Mbana, P. (2006), 'African Challenges': Using Law for Good Governance and Development, Africa World Press: USA.

Sen, A. (1999), Development as freedom, Alfred A. Aknopf: New York.

Transparency International (2006), Corruption Perception Index: TI.

UNDP (2006), Human Development Report, United Nations Development Programme Oxford University Press: New York.

United Nations Office on Drug and Crime (2005), Crime and development in Africa (2005), UNODC: New York.

Vuuren, H. (2006), Apartheid Grand Corruption, Assessing the Scale of Crimes of Profit in South Africa from 1970 to 1994; a report prepared by civil society at the request of the Second National Anti-Corruption Summit, May, 2006.Center for Conflict Studies: Cape Town.

Wanyande, P. (1997), State Driven Conflict in the Greater Horn of Africa, Revised Paper Presented at the USAID Organized workshop on Conflict in the Great Horn of Africa May 21-23, Methodist House: Nairobi.

Wentling, M. (2002), 'My 30 Years in Africa: Still Searching for Answers', American Foreign Service Association (AFSA): 2101 E Street NW, Washington, DC 20037.

Wisner, B. (1988), Power and Need in Africa; Basic Human Needs and Development Policies, Earthscan Publication Ltd: London.

World Bank (2004), 'Post-Conflict Peace Building in Africa: The Challenge of Socio-Economic Recovery and Development; Africa Regional Working Paper Series No. 73, October 2004.

World Bank (2005), Population data from Word Bank, World Development Indicators 2005, at www.worldbank.org/data/onlinedatabases/onlinedata-bases.html (12/02/06).

World Bank (2006), Africa Development Indicator: Washington D.C.

Wrong, M. (2005), When the Money goes west, New Statesman March 14, 2005. 
Table 1. Kenya is employed for Illustration

$\rightarrow$ Data before corrupt regime $\quad \leftarrow \quad \rightarrow \quad$ Data during and after corrupt regime $\quad \leftarrow$

\begin{tabular}{|c|c|c|c|c|c|c|}
\hline $\begin{array}{l}\text { Poverty } \\
\text { (national } \\
\text { income) }\end{array}$ & Conflict & $\begin{array}{l}\text { Devp. } \\
\text { (GDP) }\end{array}$ & $\begin{array}{l}\text { Country, } \\
\text { corrupt } \\
\text { regime(s) } \\
\text { and amount } \\
\text { embezzled }\end{array}$ & $\begin{array}{l}\text { Poverty (national } \\
\text { income) }\end{array}$ & Conflict & Devp. (GDP) \\
\hline $\begin{array}{l}\text { Poverty } \\
\text { was at } 27 \% \\
\text { and Gini at } \\
0.40 \quad \text { by } \\
1982\end{array}$ & $\begin{array}{l}\text { Less } \\
\text { internal } \\
\text { conflict as } \\
1981\end{array}$ & $\begin{array}{l}\text { GDP in } \\
1979 \\
4.2 \%\end{array}$ & $\begin{array}{l}\text { Kenya: A. } \\
\text { Moi } \\
(1978-02) \\
\$ 1 b\end{array}$ & $\begin{array}{l}\text { Poverty increased } \\
\text { to } 30 \% \text {, and Gini } \\
\text { increased to } 0.49 \text { in } \\
1991\end{array}$ & $\begin{array}{l}\text { Conflict rose } \\
\text { between } \\
1991 / 92\end{array}$ & $\begin{array}{l}\text { Aid embargo } \\
\text { for lack of } \\
\text { governance in } \\
\text { early } 90 \mathrm{~s} \\
\text { GDP in } 1991 \text {, } \\
2.1 \% \text { and } \\
1992,0.5 \%\end{array}$ \\
\hline
\end{tabular}

Sources: For Poverty see Kayyizi-Mugerawa (2001: 6), for Development see Okafor (2004: 67), for corrupt embezzlement, see Azami (2005: 2), for Conflict see Wayande (1997:6), also see Appendix A.

This Table illustration with Kenya demonstrates that political corruption causes or worsens the state of poverty, which leads to conflicts, with the negative impacts that hinder development.

Table 2. Illustration with the entire Africa and Sub-Sahara

\begin{tabular}{|c|c|c|c|}
\hline \multicolumn{4}{|c|}{ Entire Africa and Sub-Sahara within the last three decades } \\
\hline $\begin{array}{l}\text { Corruption: as at } \\
1999 \text { African leaders } \\
\text { had stowed } \$ 20 \mathrm{bn} \text { in } \\
\text { Swiss bank account, } \\
\text { and total of } \$ 33 \mathrm{bn} \\
\text { out of Africa. }\end{array}$ & $\begin{array}{l}\text { Poverty: as } 2002 \text {, } \\
\text { half of } \\
\text { Sub-Saharan Africa } \\
\text { lives on less than } \\
\text { the equivalent of } \\
65 \text { US cents per } \\
\text { day. }\end{array}$ & $\begin{array}{l}\text { Conflict: of } 116 \text { conflicts } \\
\text { recorded by UNDP since the end } \\
\text { of the Cold War (1989), only } \\
\text { seven were between states }-109 \\
\text { were internal, and Africa had } \\
\text { more than } 32 \text { of these between } \\
\text { 1989-03. }\end{array}$ & $\begin{array}{l}\text { Development: GDP per } \\
\text { capita declined in } \\
\text { Sub-Saharan Africa by } \\
0.8 \% \text { per annum over the } \\
1975-2002 \text { periods. }\end{array}$ \\
\hline
\end{tabular}

Sources: On Corruption, see Wrong (2005) and Okafor (Ibid), on see Poverty UNODC (2005: 2), on Conflict, see Erikson and Wallenstein (2004: 625-636) and on Development, see UNODC (2005: 2). See also Appendixes A and B.

Table 3. establishes that in the entire Africa and Sub-Sahara within the last three decades political corruption worsens the state of poverty, which leads to more conflict and all this has retarded development in the Sub-Saharan Africa.

\section{APPENDIXES}

Appendix A: Political Corruption: Causal Link - Demonstration and Explanation for Poverty, Conflict and Development in Africa:

\begin{tabular}{|c|c|c|c|c|c|c|}
\hline \multirow[t]{2}{*}{ Data } & fore corrup & governm & & \multicolumn{3}{|c|}{ Data during and after corrupt government } \\
\hline & & $\leftarrow$ & & $\rightarrow$ & & $\leftarrow$ \\
\hline $\begin{array}{l}\text { Poverty } \\
\text { (national } \\
\text { income) }\end{array}$ & $\begin{array}{l}\text { Peace } \\
\text { (conflict } \\
\text { and } \\
\text { crime) }\end{array}$ & $\begin{array}{l}\text { Devp. } \\
\text { (GDP) }\end{array}$ & $\begin{array}{l}\text { Country, } \\
\text { corrupt } \\
\text { regime(s) and } \\
\text { amount } \\
\text { embezzled }\end{array}$ & $\begin{array}{l}\text { Poverty } \\
\text { (national } \\
\text { income) }\end{array}$ & $\begin{array}{l}\text { Peace } \\
\text { (conflict } \\
\text { and crime) }\end{array}$ & Devp. (GDP) \\
\hline NA & $\begin{array}{l}\text { (a) } \\
\text { Conflict } \\
\text { and crime } \\
\text { high }\end{array}$ & $\begin{array}{l}\text { (b) By } \\
1980 \\
861 \text { per } \\
\text { capita }\end{array}$ & $\begin{array}{l}\text { (c) Angola: J. } \\
\text { Santos } \\
\text { (1979-cont.) } \\
\$ 4 b\end{array}$ & $\begin{array}{l}\text { (d) Within this } \\
\text { period } 3.7 \mathrm{~m} \\
\text { children } \\
\text { malnourished }\end{array}$ & $\begin{array}{l}\text { (a) Conflict } \\
\text { and crime } \\
\text { intensify and } \\
\text { citizens } \\
\text { displaced }\end{array}$ & $\begin{array}{lcc}\text { (b) } 1990 & 804 \\
\text { and } 1998 & 651 \\
\text { per capita } & \end{array}$ \\
\hline $\begin{array}{l}\text { (e) } \\
\text { Impressive }\end{array}$ & $\begin{array}{l}\text { (a) } \\
\text { Absence } \\
\text { of conflict }\end{array}$ & $\begin{array}{l}\text { (b) By } \\
1980 \\
1,077\end{array}$ & $\begin{array}{lc}\text { Botswana } & \text { (no } \\
\text { record } & \text { of }\end{array}$ & e) impressive & $\begin{array}{l}\text { (a) Peace } \\
\text { continue to }\end{array}$ & $\begin{array}{l}\text { (b) } 19902,222 \\
19992,612\end{array}$ \\
\hline
\end{tabular}




\begin{tabular}{|c|c|c|c|c|c|c|}
\hline & and crime & p.capita & embezzlement) & & flourish & \\
\hline-- & -- & -- & $\begin{array}{l}\text { (j) Equatorial } \\
\text { Guinea: T. } \\
\text { Obiag } \\
\text { (1979-cont.) } \\
\$ 1.2 b\end{array}$ & -- & $\begin{array}{l}\text { (a) Conflict } \\
\text { and crime } \\
\text { since } \\
2000-01\end{array}$ & -- \\
\hline $\begin{array}{l}(\mathrm{f}) \quad(\mathrm{g}) \\
\text { Poverty } \\
\text { was at } 27 \% \\
\text { and Gini at } \\
0.40 \quad \text { by } \\
1982\end{array}$ & $\begin{array}{l}\text { (s) Less } \\
\text { internal } \\
\text { conflict } \\
\text { and crime } \\
\text { as at } \\
1981 \text { until } \\
\text { next } \\
\text { decade }\end{array}$ & $\begin{array}{l}\text { (f) GDP } \\
\text { in } 1979 \\
4.2 \%\end{array}$ & $\begin{array}{lr}(\mathrm{c} / \mathrm{h}) & \text { Kenya: } \\
\text { A. } & \text { Moi } \\
(1978-02) & \$ 1 \mathrm{~b}\end{array}$ & $\begin{array}{l}\text { (f) (g) Poverty } \\
\text { increased to } \\
30 \% \text {, and Gini } \\
\text { increased to } \\
0.49 \text { in } 1991\end{array}$ & $\begin{array}{l}\text { (s) Conflict } \\
\text { and crime } \\
\text { rose } \\
\text { between } \\
\text { 1991/92 }\end{array}$ & $\begin{array}{l}\text { (f) Aid embargo } \\
\text { for lack of } \\
\text { governance in } \\
\text { early 90s GDP } \\
\text { in 1991, } 2.1 \% \text {, } \\
\text { and } 1992,0.5 \% \\
\text { and } 0.2 \% \text { in } \\
1993\end{array}$ \\
\hline-- & $\begin{array}{l}\text { (a) } \\
\text { Conflict } \\
\text { and crime } \\
\text { low }\end{array}$ & $\begin{array}{l}\text { (b) } 1980 \\
444 \\
\text { p.capita }\end{array}$ & $\begin{array}{l}\text { (i) Liberia: S. } \\
\text { Doe (1986-90) } \\
\$ 1.5 b\end{array}$ & -- & $\begin{array}{l}\text { (a) Conflict } \\
\text { and crime } \\
1989-03\end{array}$ & $\begin{array}{l}\text { (a) } 1990 \quad 203 \text {, } \\
\text { '99 } 153 \text { p.capita }\end{array}$ \\
\hline $\begin{array}{l}\text { (e) } \\
\text { impressive }\end{array}$ & $\begin{array}{l}\text { (a) } \\
\text { Absence } \\
\text { of conflict } \\
\text { and crime }\end{array}$ & $\begin{array}{l}\text { (b) By } \\
1980 \\
1,570 \\
\text { per } \\
\text { capita }\end{array}$ & $\begin{array}{l}\text { Mauritius (no } \\
\text { record of } \\
\text { embezzlement) }\end{array}$ & (e) impressive & $\begin{array}{l}\text { (a) Peace } \\
\text { continue to } \\
\text { reign }\end{array}$ & $\begin{array}{l}\text { (b) } 19902,532 \\
19993,665 \text { per } \\
\text { capita }\end{array}$ \\
\hline-- & $\begin{array}{l}\text { (a) } \\
\text { Conflict } \\
\text { and crime } \\
\text { less before } \\
1975\end{array}$ & $\begin{array}{l}\text { (b) } \\
\text { Annual } \\
\text { growth } \\
1980-89 \\
(2.0 \%)\end{array}$ & $\begin{array}{lr}\text { (c) } & \text { Morocco: } \\
\text { King } & \\
\text { Mohammed } \\
\text { VI }(1999-?) \\
\text { lavish } & \$ 268 \mathrm{~m} \\
\text { yearly } & (18 \\
\text { times } & \text { more } \\
\text { than Queen } & \\
\text { Elizabeth) }\end{array}$ & $\begin{array}{l}\text { (c) Since } 1999 \\
\text { a country } \\
\text { where a fifth } \\
\left(5^{\text {th }}\right) \text { of the } \\
\text { population has } \\
\text { to survive on } \\
\text { less than } \$ 1 \\
\text { per day }\end{array}$ & $\begin{array}{l}\text { (a) Conflict } \\
\text { and crime } \\
1975-89\end{array}$ & $\begin{array}{ll}\text { (b) } & \text { Annual } \\
\text { growth } & 1990-99 \\
(0.8 \%) & \end{array}$ \\
\hline $\begin{array}{lr}(1 / \mathrm{n}) & \text { By } \\
1985 & 46 \% \\
\text { and } & \text { Gini } \\
\text { was } & 0.37\end{array}$ & $\begin{array}{l}(\mathrm{m}) \\
\text { Conflict } \\
\text { less } \\
\text { during } \\
\text { Buhari/ } \\
\text { and } \\
\text { Idiagbon } \\
\text { regime }\end{array}$ & $\begin{array}{l}\text { (g) } 1980 \\
21 \% \\
\text { growth }\end{array}$ & $\begin{array}{l}\text { (k/1) Nigeria: I. } \\
\text { Babangida } \\
(1983-92) \\
\$ 11 b \text { and } \mathrm{S} . \\
\text { Abacha } \\
(1993-98) \$ 5 b\end{array}$ & $\begin{array}{l}\text { (n) } 199868 \% \\
\text { and as at } 1992 \\
\text { Gini was up to } \\
0.416\end{array}$ & $\begin{array}{l}(\mathrm{m}) \quad(\mathrm{t}) \\
\text { Conflict } \\
\text { since 1985; } \\
\text { crime } \\
\text { increased } \\
\text { e.g. murder } \\
838 \text { in } 1998 \\
\text { to } 928 \text { in } \\
1999\end{array}$ & $\begin{array}{ll}(\mathrm{g}) \quad 1985 & 9 \%, \\
1990 & 15 \% \\
\text { growth }\end{array}$ \\
\hline NA & $\begin{array}{l}\text { (o) } \\
\text { Between } \\
1948 \\
60 \mathrm{~s} \\
\text { conflict } \\
\text { and crime } \\
\text { were not } \\
\text { severe }\end{array}$ & $\begin{array}{l}(\mathrm{g}) 1965 \\
(22 \%), \\
1970 \\
(23 \%) \\
\text { growth }\end{array}$ & $\begin{array}{lr}\text { (p) } & \text { South } \\
\text { Africa: } & \text { H. } \\
\text { Verwoerd } & \\
(1958-66) & \\
\text { \$1.7b; } & \text { P. } \\
\text { Botha } & \\
(1978-89) & \text { \$b } \\
\text { and } \quad F . W . \\
\text { De-Klerk } \\
(1989-94) & \$ 2 b\end{array}$ & $\begin{array}{l}(\mathrm{q} / \mathrm{r}) \quad 70 \mathrm{~s} \text { and } \\
80 \mathrm{~s} \text { around } \\
50 \% \text { and as at } \\
200034 \%\end{array}$ & $\begin{array}{l}\text { (o) (u) } \\
\text { Conflict } \\
\text { intense } \\
\text { between } \\
\text { 1970-94; } \\
\text { crime } \\
\text { increased } \\
\text { e.g. murder } \\
10,000 \text { to } \\
11,000 \text { by } \\
1990\end{array}$ & $\begin{array}{lr}(g) 1975 & (25 \%), \\
1980 & (23 \%), \\
1985 & (15 \%), \\
1990 & (12 \%) \\
\text { growth } & \end{array}$ \\
\hline -- & $\begin{array}{l}\text { (a) } \\
\text { Conflict }\end{array}$ & -- & $\begin{array}{l}\text { (h) Togo: G } \\
\text { Eyadema }\end{array}$ & -- & $\begin{array}{l}\text { (a) Conflict } \\
\text { and crime }\end{array}$ & -- \\
\hline
\end{tabular}




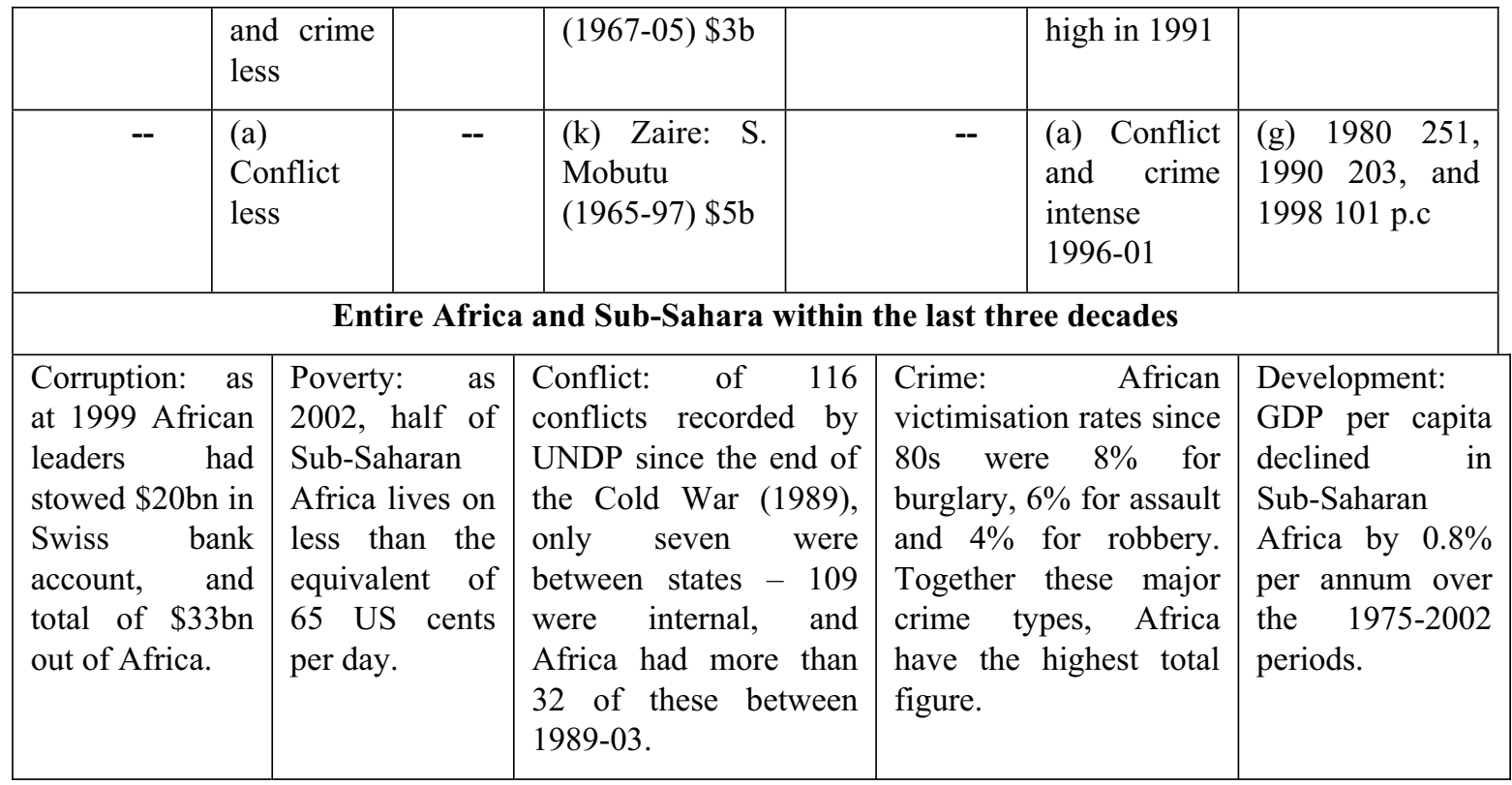

Sources: (a) Uppsala Conflict Data Programme (2003) (b) African Development Indicators (2006),(C) Azami (2005), Profligacy, corruption and debt, Daily Times (Pakistan) February 10, p.2, also available at http://www.odiousdebts.org (05/02/07) (d) Ccommission for Africa (2005), 'Our Common Interest, The Report of the Commission for Africa (e) UNDP, Human Development Report (2006), United Nations Development Programme Oxford University Press: New York (f) Okafor, C (2004), Neo-Democracy and Poverty Management in Africa, Mercury Bright Press: Awka, Nigeria p.67 (g) Kayyizi-Mugerwa, S (2001), op cit (h)Wrong, Michela (2005), When the Money goes west, New Statesman March 14, 2005, (i)encyclpadea.com,

(j)AfrolNewsavailableat http://www.uneca.org/srdc/ca/news/End\%20March/(05/02/07) (k) The Chartered Institute of Building (2004), World Bank finds corruption is costing billions in lost development power, CIOB September 29 (1) AFRODAD (2007) op cit (m) Onyeiwu, Steve (2004), On the Economic Determinants of Violent Conflict in Africa; Preliminary Evidence From Nigeria, Paper Prepared for Presentation at WIDER's Conference on Making Peace, 4-5 June, Helsinki: Finland. (n) Oxfam (2003), 'Social Development and Poverty in Nigeria', available at http://www.oxfam.org.uk/what_we_do/resources/downloads/wp-nigeria/wp-nigeria_socdev.pdf (12/8/06) (o) Regional Survey of the World, Africa and Sub Sahara (2002), Europa publication: London. (p) Vuuren H (2006), op cit (q) May, Julian (1998), Poverty and Inequality in South Africa report prepared for the office of the Executive Deputy President and Inter-Ministerial Committee for Poverty and Inequality, Pretoria S/A. (r) Bohart, H. and R. Kanbur (2006), eds., Poverty and Policy in Post Apartheid South Africa, HSRC Press: Pretoria. (s) Wayande P. (1997), State Driven Conflict in the Greater Horn of Africa, paper presented at the USID Organized workshop on Conflict in the Greater Horn of Africa, Methodist Guest House: Nairobi, (t) Trends in Crime (2002). (u) Robert Winslow (2002), A Comparative Criminology Tour of the World, South Africa: San Diego State University.

For Africa and Sub-Sahara - on Corruption Wrong (Ibid) and Okafor (Ibid), on Poverty UNODC (2005: 2), on Conflict Erikson and Wallenstein (2004: 625-636) and on Development UNODC (2005: 2).

Appendix B: Comparative studies of conflicts in selected African countries (1960-2007)

\begin{tabular}{|l|l|l|l|l|}
\hline Countries & Internal/external & $\begin{array}{l}\text { Communal } \\
\text { aggression }\end{array}$ & $\begin{array}{l}\text { Civil strife, riots } \\
\text { and volitical } \\
\text { demonstrations }\end{array}$ & $\begin{array}{l}\text { violence } \\
\text { violent }\end{array}$ \\
\hline
\end{tabular}

\begin{tabular}{|l|l|c|c|c|}
\hline $\begin{array}{l}\text { Democratic } \\
\text { Republic of } \\
\text { Congo }\end{array}$ & $\begin{array}{l}\text { Internal with external } \\
\text { participation }\end{array}$ & Very high & Low & High \\
\hline Mauritius & Not reported & Normal & Normal & Normal \\
\hline Egypt & Internal & Average & Average & High \\
\hline Nigeria & Against Cameroon & Very high & Very high & Very high \\
\hline
\end{tabular}




\begin{tabular}{|l|l|c|c|c|}
\hline Rwanda & $\begin{array}{l}\text { Internal with foreign } \\
\text { involvement }\end{array}$ & Very high & Low & High \\
\hline Sierra Leone & $\begin{array}{l}\text { Internal with foreign } \\
\text { involvement }\end{array}$ & Very high & High & Very high \\
\hline South Africa & Not reported & Very high & Very high & High \\
\hline Ethiopia & Internal & High & Average & low \\
\hline Botswana & Not reported & Normal & Very low & rationship \\
\hline
\end{tabular}

Sources: Uppsala Conflict Data Programme (2003 in UNODC, p.17), Ikejiaku, B. (2008), The relationship between poverty, peace and development in Africa, political corruption emphasised 1960-2007: case studies of Nigeria and South Africa, unpublished (submitted) PhD Thesis, School of Politics, International Relations and Philosophy, Keele University, United Kingdom. Note: 'not reported' means absence of conflict or data unavailable; 'normal' means absence of conflict reported, while very low, low, average, high and very high are rated based on number of occurrence, intensity and duration of the conflict. 